\title{
Mixed ubiquitin chains regulate DNA repair
}

\author{
Gergely Rona $^{1,2}$ and Michele Pagano ${ }^{1,2,3}$ \\ ${ }^{1}$ Department of Biochemistry and Molecular Pharmacology; ${ }^{2}$ Perlmutter Cancer Center; ${ }^{3}$ Howard Hughes Medical Institute, \\ New York University School of Medicine, New York, New York 10016, USA
}

Diverse linkage in polyubiquitin chain structure gives cells an unparalleled complexity to virtually modulate all aspects of cell biology. Substrates can be covalently modified by ubiquitin chains of different topology. Proper DNA damage response takes advantage of this regulatory system and heavily relies on ubiquitin-based signaling. Moreover, increasing evidence suggests that chain specificity dictates DNA repair outcome. In this issue of Genes \& Development, Wu and colleagues (pp. 1702-1717) show that Cezanne and Cezanne2, two paralogous deubiquitinating enzymes that are recruited to sites of DNA damage, ensure proper local polyubiquitin chain composition for downstream DNA repair protein assembly. Their study offers a key insight into the mechanism of crosstalk between linkage-specific ubiquitylation at DNA damage sites, while simultaneously raising important questions for future research.

The ubiquitin landscape is key for propagating and finetuning the DNA damage response (DDR) as shown by ever-growing evidence over the last decade (Schwertman et al. 2016). Target proteins can be polyubiquitylated by ubiquitin chains in which ubiquitin moieties are linked through their seven lysine residues (Lys6, 11, 27, 29, 33, 48 , and 63 ) or through the $\mathrm{N}$-terminal methionine, resulting in chains with distinct topologies that orchestrate different biological outputs (Komander and Rape 2012; Swatek and Komander 2016; Haakonsen and Rape 2019). Homotypic chains are connected through the same ubiquitin residue, whereas heterotypic chains are built up by ubiquitin monomers linked through different residues. However, chain complexity does not stop here since these polymers could branch out when a subunit is modified on two or more residues at the same time (Haakonsen and Rape 2019). Proteasomal degradation through Lys48linked ubiquitin chains, as well as signaling events driven by Lys63-linked ubiquitin chains, have been attributed to proper DDR signaling. Although other linkage-specific ubiquitylation events have been documented during

[Keywords: Cezanne; DNA damage response; polyubiquitin] Corresponding author: michele.pagano@nyulangone.org Article is online at http://www.genesdev.org/cgi/doi/10.1101/gad.334383. 119.
DDR (Elia et al. 2015), their functional roles remain largely unclear.

In response to double stranded breaks (DSBs), one of the earliest enzymes involved is the RING Finger ubiquitin ligase 8 (RNF8), which decorates histone $\mathrm{H1}$ and L3MBTL2 with Lys63-linked ubiquitin chains, generating a platform for the recruitment of downstream repair proteins (e.g., 53BP1 and BRCA1) (Uckelmann and Sixma 2017; Nowsheen et al. 2018). Subsequently, through the combined action of RNF8 and RNF168, Lys63-linked, Lys48-linked, and Lys27-linked ubiquitin chains can arise at DSBs (Lok et al. 2012; Gatti et al. 2015). Recently, RNF8 was also shown to propagate Lys11 chains at DSBs with the help of the ubiquitin-conjugating enzyme, UBE2S, in an ATM-dependent fashion. Interestingly, this activity of RNF8 is antagonized by the deubiquitinating enzyme (DUB) Cezanne, which has a high specificity for Lys11 polyubiquitin chains (Mevissen et al. 2013; Paul and Wang 2017). Local enrichment of these chains has been proven to be necessary for proper DNA damage-induced transcriptional silencing, complementing $\mathrm{H} 2 \mathrm{~A}$ monoubiquitylation by the cPRC1 and ncPRC1.1 complexes (Wang et al. 2004; Shanbhag et al. 2010; Rona et al. 2018). Just by looking at RNF8, RNF168, and the different types of polyubiquitin chains they build, one could argue for the existence of a potential crosstalk between linkagespecific ubiquitination at the site of DNA damage. Therefore, it is important to gain a better understanding of how the polyubiquitin chain profile at DNA damage sites is regulated.

Wu et al. (2019) showed how local Lys11 and Lys63 polyubiquitin chain composition at DSBs dictate downstream DNA repair protein recruitment. The polyubiquitin chain profile generated by the ligase activity of RNF8 (either through utilizing UBCH8 for Lys48-linked chains, UBC13 for Lys63-linked chains, or UBE2S for Lys11linked chains) is fine-tuned by the Cezanne and Cezanne2, novel "readers" and "erasers" of the polyubiquitin signal at DSBs.

(C) 2019 Rona and Pagano This article is distributed exclusively by Cold Spring Harbor Laboratory Press for the first six months after the full-issue publication date (see http://genesdev.cshlp.org/site/misc/terms.xhtml). After six months, it is available under a Creative Commons License (Attribution-NonCommercial 4.0 International), as described at http://creativecommons.org/licenses/by-nc/4.0/. 
The nucleating role of Lys63-linked chains is demonstrated by the fact that there is no proper DSB repair without UBC13 (Zhao et al., 2007). Therefore, identification of novel responders to these emerging chains might give a better understanding of DNA repair processes. To this end, Wu et al. (2019), using a protein array-based screening, identified the ubiquitin-associated (UBA) domains of Cezanne and Cezanne2 as novel and specific binders of Lys63-linked polyubiquitin chains. Accordingly, Cezanne is recruited to laser-induced damage sites in a UBA domain-dependent manner and is necessary for proper DNA damage repair. The authors had previously shown that UBE2S depletion does not impair the recruitment of 53BP1 and components of the BRCA1-A complex (BRCA1, Rap80, and Ambraxas) to ionizing radiation induced foci (IRIF). In fact, the recruitment of these proteins relies on the Lys63-linked chains, not Lys11-linked chains. However, depletion of Cezanne led to fewer number of cells with Rad18 and BRCA1-A IRIF, while not affecting the formation of $\gamma \mathrm{H} 2 \mathrm{~A} . \mathrm{X}, 53 \mathrm{BP} 1$, and RNF168 foci. Rescue experiments proved that this function of Cezanne relies on its UBA domain and its Lys11-specific DUB activity. In favor of this hypothesis, codepletion of UBE2S rescued the phenotypes of Cezanne knockdown cells: (1) the formation of BRCA1-A foci, (2) the cell's ability to repair DNA lesions (assayed by the disappearance of $\gamma$ H2A.X foci over time), and (3) IR sensitivity. In vitro binding assays showed that the ubiquitin interacting motif of Rap80 is inhibited by Lys11-linked ubiquitin moieties present in a Lys63-linked chain. Therefore, Cezanne seems to facilitate the recruitment of downstream repair proteins by limiting mixed Lys11/Lys63 branched polyubiquitin chains in favor of chains with Lys63 linkages. The authors also looked at the contribution of Cezanne2, a paralog of Cezanne with similar Lys11-specific activity and a similar UBA motif capable of binding Lys63-linked chains. Cezanne2 does not seem to be redundant with Cezanne, but facilitates the function of the latter. On its own it is unable to affect the formation of BRCA1-A IRIF, as well as other phenotypes associated with Cezanne depletion. However, when the authors codepleted Cezanne and Cezanne2, they consistently observed more severe phenotypes.

The work by Wu et al. (2019) raises several questions for the field. What does regulate the interaction of RNF8 with at least three different ubiquitin-conjugating enzymes? How does the ATM-dependent, RNF8-mediated Lys11linked ubiquitin chains act together with the PARP1-dependent, cPRC1- and ncPRC1.1-mediated transcriptional repression at DNA lesions? Do Cezanne and Cezanne2 activity antagonize local transcriptional repression? What other ubiquitin chains contribute to DNA repair and in what way? And, finally and more generally, what are the other readers and writers of this "ubiquitin-code" at DSBs?

The work described here shows that the ubiquitin signal at DNA damage sites is even more complex than assumed before and reminds us that polyubiquitin-linkage specificity dictates signaling events that need to be investigated in detail.

\section{References}

Elia AE, Boardman AP, Wang DC, Huttlin EL, Everley RA, Dephoure N, Zhou C, Koren I, Gygi SP, Elledge SJ. 2015. Quantitative proteomic Atlas of ubiquitination and acetylation in the DNA damage response. Mol Cell 59: 867-881. doi:10.1016/j.molcel.2015.05.006

Gatti M, Pinato S, Maiolica A, Rocchio F, Prato MG, Aebersold R, Penengo L. 2015. RNF168 promotes noncanonical K27 ubiquitination to signal DNA damage. Cell Rep 10: 226-238. doi:10.1016/j.celrep.2014.12.021

Haakonsen DL, Rape M. 2019. Branching out: improved signaling by heterotypic ubiquitin chains. Trends Cell Biol 29: 704-716. doi:10.1016/j.tcb.2019.06.003

Komander D, Rape M. 2012. The ubiquitin code. Annu Rev Biochem 81: 203-229. doi:10.1146/annurev-biochem-060310170328

Lok GT, Sy SM, Dong SS, Ching YP, Tsao SW, Thomson TM, Huen MS. 2012. Differential regulation of RNF8-mediated Lys48- and Lys63-based poly-ubiquitylation. Nucleic Acids Res 40: 196-205. doi:10.1093/nar/gkr655

Mevissen TE, Hospenthal MK, Geurink PP, Elliott PR, Akutsu M, Arnaudo N, Ekkebus R, Kulathu Y, Wauer T, El Oualid F, et al. 2013. OTU deubiquitinases reveal mechanisms of linkage specificity and enable ubiquitin chain restriction analysis. Cell 154: 169-184. doi:10.1016/j.cell.2013.05.046

Nowsheen S, Aziz K, Aziz A, Deng M, Qin B, Luo K, Jeganathan KB, Zhang H, Liu T, Yu J, et al. 2018. L3MBTL2 orchestrates ubiquitin signalling by dictating the sequential recruitment of RNF8 and RNF168 after DNA damage. Nat Cell Biol 20: 455-464. doi:10.1038/s41556-018-0071-x

Paul A, Wang B. 2017. RNF8- and Ube2S-dependent ubiquitin lysine 11-linkage modification in response to DNA damage. Mol Cell 66: 458-472.e5. doi:10.1016/j.molcel.2017.04.013

Rona G, Roberti D, Yin Y, Pagan JK, Homer H, Sassani E, Zeke A, Busino L, Rothenberg E, Pagano M. 2018. PARP1-dependent recruitment of the FBXL10-RNF68-RNF2 ubiquitin ligase to sites of DNA damage controls H2A.Z loading. Elife 7: e38771. doi:10.7554/eLife.38771

Schwertman P, Bekker-Jensen S, Mailand N. 2016. Regulation of DNA double-strand break repair by ubiquitin and ubiquitinlike modifiers. Nat Rev Mol Cell Biol 17: 379-394. doi:10 $.1038 / \mathrm{nrm} .2016 .58$

Shanbhag NM, Rafalska-Metcalf IU, Balane-Bolivar C, Janicki SM, Greenberg RA. 2010. ATM-dependent chromatin changes silence transcription in cis to DNA double-strand breaks. Cell 141: 970-981. doi:10.1016/j.cell.2010.04.038

Swatek KN, Komander D. 2016. Ubiquitin modifications. Cell Res 26: 399-422. doi:10.1038/cr.2016.39

Uckelmann M, Sixma TK. 2017. Histone ubiquitination in the DNA damage response. DNA Repair 56: 92-101. doi:10 .1016/j.dnarep.2017.06.011

Wang H, Wang L, Erdjument-Bromage H, Vidal M, Tempst P, Jones RS, Zhang Y. 2004. Role of histone H2A ubiquitination in Polycomb silencing. Nature 431: 873-878. doi:10.1038/nature02985

Wu X, Liu S, Sagum C, Chen J, Singh R, Chaturvedi A, Horton JR, Kashyap TR, Fushman D, Cheng X, et al. 2019. Crosstalk between Lys63- and Lys11-polyubiquitin signaling at DNA damage sites is driven by Cezanne. Genes Dev (this issue). doi:10 $.1101 /$ gad.332395.119

Zhao GY, Sonoda E, Barber LJ, Oka H, Murakawa Y, Yamada K, Ikura T, Wang X, Kobayashi M, Yamamoto K, et al. 2007. A critical role for the ubiquitin-conjugating enzyme Ubc13 in initiating homologous recombination. Mol Cell 25: 663-675. doi:10.1016/j.molcel.2007.01.029 


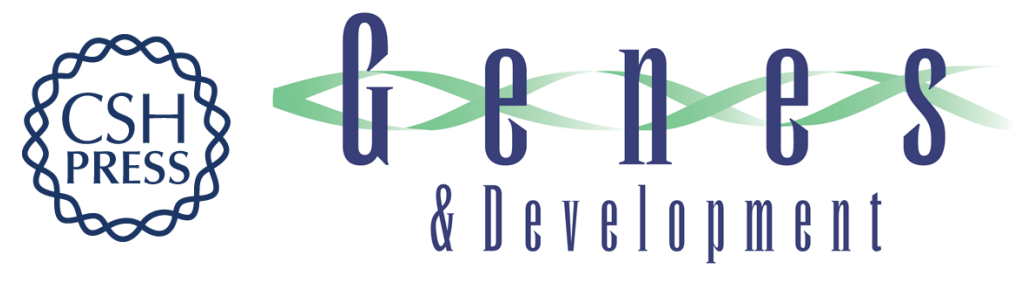

\title{
Mixed ubiquitin chains regulate DNA repair
}

\author{
Gergely Rona and Michele Pagano
}

Genes Dev. 2019, 33:

Access the most recent version at doi:10.1101/gad.334383.119

\section{Related Content Crosstalk between Lys63- and Lys11-polyubiquitin signaling at DNA damage sites is driven by Cezanne \\ Xiao Wu, Shichang Liu, Cari Sagum, et al. \\ Genes Dev. December , 2019 33: 1702-1717}

References This article cites 16 articles, 1 of which can be accessed free at:

http://genesdev.cshlp.org/content/33/23-24/1615.full.html\#ref-list-1

Articles cited in:

http://genesdev.cshlp.org/content/33/23-24/1615.full.html\#related-urls

Creative This article is distributed exclusively by Cold Spring Harbor Laboratory Press for the first Commons

License

six months after the full-issue publication date (see

http://genesdev.cshlp.org/site/misc/terms.xhtml). After six months, it is available under a Creative Commons License (Attribution-NonCommercial 4.0 International), as described at http://creativecommons.org/licenses/by-nc/4.0/.

Email Alerting Receive free email alerts when new articles cite this article - sign up in the box at the top Service right corner of the article or click here.

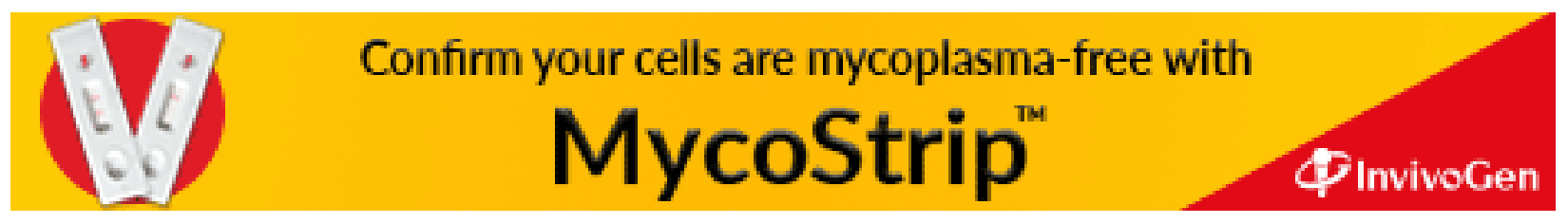

